Folia primat. 1973;20:I-IV

\title{
Contents, Vol. 20, 1973
}

Editor: Editorial Board:

J. Biegert, Zurich E. L. Bone, Louvain W. Fiedler, Wien H. F. Harlow, Madison, Wise. H. Hediger, Zurich W. C. Osman Hill, Folkestone

H. Hofer, Covington, La.

J. Hürzeler, Basel

J. R. Napier, London

J. Piveteau, Paris

A. Remane, Kiel

A. H. Schultz, Zurich

D.Starck,

Frankfurt am Main

W.L.Straus, Jr., Baltimore, Md. S.L. Washburn, San Francisco, Calif. H. Zapfe, Wien S. Zuckerman, Birmingham

\section{SWK}

S. Karger $\cdot$ Basel $\cdot$ München $\cdot$ Paris $\cdot$ London $\cdot$ New York $\cdot$ Sydney

S. Karger · Basel घ München · Paris · London · New York · Sydney Arnold-Böcklin-Strasse 25, CH-4011 Basel (Switzerland)

All rights, including that of translation into other languages, reserved. Photomechanic reproduction (photocopy, microcopy) of this volume or parts thereof without special permission of the publishers is prohibited.

(C) Copyright 1973 by S. Karger AG, Verlag für Medizin und Naturwissenschaften, Basel Printed in Switzerland by Unionsdruckerei, Berne

Contents

Schön, M. A. and Ziemer, L. K.: Wrist Mechanism and Locomotor Behavior of Dryopithecus (Proconsul) africanus 1

Groves, C. P.: Notes on the Ecology and Behaviour of the Angola Colobus

(Colobus angolensis P. L. Sclater 1860) in N. E. Tanzania 12

Baldwin, J. D. and Baldwin, J. I.: Interactions between Adult Female and In fant Howling Monkeys (Alouatta palliata) 27

Maller, O.: Quality and Intensity of Sugar Solutions as Determinants of Ingestion by the Rhesus Monkey (Macaca mulatto) 72

Teleki, G.: Group Response to the Accidental Death of a Chimpanzee in Gombe National Park, Tanzania 81

La Salle, M.: Interrelationship of Blood Groups between Rhesus Macaques 
(Macaca mulatta) and Celebes Ape (Macaca niger) 95

Brumback, R. A. and Willenborg, D. O.: Serotaxonomy of Aotus. A Preliminary

Study 106

Meier, R. J.: Consideration of Function in Macaque Dermatoglyphics 112

Lessertisseur, J. et Jouffroy, F. K.: Tendances locomotrices des primates traduites par les proportions du pied. L'adaptation à la bipédie (Locomotory Trends in Primates Expressed by the Foot Ratios. The Adaptation to Bipedalism) $\quad 125$

Grubb, P.: Distribution, Divergence and Speciation of the Drill and Mandrill 161 Breuggeman, J. A.: Parental Care in a Group of Free-Ranging Rhesus Monkeys (Macaca mulatta) 178

Candland, D. K.; Dresdale, L.; Leiphart, J.; Bryan, D.; Johnson, C, and Nazar, B.: Social

Structure of the Squirrel Monkey \{Saimiri sciureus, Iquitos): Relationships among Behavior, Heartrate, and Physical Distance 211

Coimbra-Filho, A. F. and Mittermeier, R. A.: New Data on the Taxonomy of the Brazilian Marmosets of the Genus Callithrix Erxleben, $1777 \quad 241$

Cherkovich, G. M. and Tatoyan, S. K.: Heart Rate (Radiotelemetrical Registra tion) in Macaques and Baboons According to Dominant-Submissive Rank in a Group 265

Greenfield, L. O.: Note on the Placement of the Most Complete 'Kenyapithecus africanus' Mandible 274

Leutenegger, W.: Maternal-Fetal Weight Relationships in Primates

Meinel, W. und Woehrmann-Repening, A.: Zur Morphologie und Histologie des Geruchsorgans von Tupaia glis (Diard 1820). The Morphology and His tology of the Olfactory Organ of Tupaia glis 294

Vu, S.; Kanagasuntheram, R., and Krishnamurti, A.: Sensory Nerve Termina tions in the Oral Tissues of Some Pongidae 312

Allen, R. C. and Buettner-Janusch, J.: Red Cell and Serum Proteins of

Patas Monkeys, Cercopithecus ( = Erythrocebus) patas 321

Etter, H. F.: Terrestrial Adaptations in the Hands of Cercopithecinae

Zingeser, M. R.: Dentition of Brachyteles arachnoides with Reference to Alouattine and Atelinine Affinities 351

IV

Contents

Brehme, H. und Wiersema, H. D.: Finger- und Zehenbeerenmuster von Pongoiden

(Fingertip and Toetip Patterns of the Pongidae) 391

Loo, S. K.: A Comparative Study of the Nasal Fossa of Four Nonhuman

Primates $\quad 410$

Happold, D. C. D.: The Red Crowned Mangaby, Cercocebus torquatus, in

Western Nigeria 423

Welker, C.: Ethologische Bedeutung des Harnwaschens von Galago crassicaudatus E. Geoffroy, 1812 (Lorisiformes: Galagidae) (Ethological Importance of

Urine-Washing of Galago crassicaudatus) 429

Savage, E. S.; Temerlin, J. W., and Lemmon, W. B.: Group Formation among

Captive Mother-Infant Chimpanzees (Pan troglodytes) 453

Book Reviews · Buchbesprechungen · Livres nouveaux 78, 474 
Author Index 476 